\title{
Financial Literacy, Behavioral Biases and Investor's Portfolio Diversification: Empirical Study of an Emerging Stock Market
}

\author{
Muhammad Anwar * $\quad$ Sher Zaman Khan ${ }^{\dagger} \quad$ Amin Ur Rehman ${ }^{\ddagger}$
}

\begin{abstract}
The purpose of this study is to check the impact of financial literacy and behavioral biases on investor's portfolio diversification. Data were collected through questionnaire using sample size of 181 investors trading in Pakistan Stock Market. The results indicate that financial literacy has insignificant and positive influence on investor's portfolio diversification, behavioral biases such as familiarity and availability biases have insignificant and negative while overconfidence bias has significant negative impact on investor's portfolio diversification. Portfolio size also has significant positive impact on portfolio diversification. The findings suggest the implementation of financial literacy programs to facilitate the investors, trading in different stocks. The implications for practice were discussed in detail.
\end{abstract}

Keywords: Financial literacy; familiarity bias; availability bias; overconfidence bias; portfolio size; portfolio diversification.

\section{Introduction}

From rational prospective, Investor's portfolio diversification has been studied extensively but behavior of investors about diversification has not yet been fully studied particularly in developing and under-developed markets. Rational theories about portfolio diversification, mainly discussed in literatures are firstly proposed by Markowitz (1952) elucidated that investors combine different assets to minimize risk and maximize return to make an efficient portfolio. Thereafter, Sharpe (1964) developed the CAPM (Capital Assets Pricing Model) which extensively debated in the world of finance. This model is used to know the return of an asset, given a certain level of risk that the investor is willing to take. Similarly, the other researchers such as Lintner (1965); Ross (1976); Black (1972); Roll (1977); Fama and French (1992) debated the theory of Markowitz and made further contribution in the field. However, irrationality, psychological factors and behavioral biases play significant role in investor's portfolio diversification which preliminary begun when Kahneman and Tversky (1972) proposed different behavioral theories. Lee, Shleifer, and Thaler (1991) defined behavioral finance as "a fast growing area that is concerned with the impact of

\footnotetext{
*Faculty of Management Sciences,International Islamic University, Islamabad, Pakistan.

E-mail: m.anwar.ims@gmail.com.

${ }^{\dagger}$ University of Science and Technology, Beijing, China.

E-mail: shkhan_21@yahoo.com.

${ }^{\ddagger}$ Faculty of Management Sciences, International Islamic University, Islamabad, Pakistan.

E-mail: aminrahman42@gmail.com.
} 
psychology on the behavior of financial practitioners".

In behavioral finance, literature evidenced that investors do not behave rationally. For instance, Daniel, Hirshleifer, and Teoh (2002) scrutinized that markets are not efficient and investor's biases have significant influence on stock prices. According to Singh (2012), Efficient Market Hypothesis (EMH) proposed that investors are rational and they are utility maximizing personalities. While, on the other hand cognitive psychology suggests that investment decisions making is influenced by several cognitive illusions such as overconfidence, representativeness, anchoring, gambler fallacy and loss aversion etc. Behavioral biases have several types, which play a key role in the world of finance (Bhutta \& AliShah, 2015). In addition, Aren and Aydemir (2015) explicated that investment decisions can be affected by several demographic factors, such as age, gender, marital status. Many researchers have scrutinized that financial literacy influences investor's portfolio diversification (Mouna \& Jarboui, 2015; Letkiewicz \& Fox, 2014; Chu, Wang, Xiao, \& Zhang, 2016). For instance, Zhang (2014) and Mian (2014) scrutinized that financial literate individuals are more likely to participate in financial market because they have more information about stock markets. He also finalized that male investors are more financial literate and more likely to engage in stock market. Mouna and Anis (2013) suggested that easy economic and financial stability requires financial information. Abreu (2010) observed that financial literate individuals take more care about their portfolio diversification. They also suggested that financial education and quality of information have more influence on investor's portfolio diversification. (In behavioral finance approach, people are normal, not rational). So normal people are influenced by several cognitive biases. But individuals must have knowledge about sociology, psychology and financial concepts which help them in efficient financial decision making (Bhutta \& AliShah, 2015).

Recently, the area of behavioral finance and financial literacy has grabbed much attention of researchers. Many researchers have focused on financial literacy, behavioral and psychological influence on investor's investment decision (Prosad, Kapoor, \& Sengupta, 2015; Hoffmann, Post, \& Pennings, 2013; Kumar \& Goyal, 2016; Pikulina, Renneboog, \& Tobler, 2017). Very few studies have focused on behavior and portfolio diversification (Shinagawa, 2014; Jacobs, Muller, \& Weber, 2014; Fuertes, Muradoglu, \& Ozturkkal, 2012; Mouna \& Anis, 2015). In addition, few studies have been conducted in Pakistan slightly related to this study (Ghaffar \& Sharif, 2016a; Awais, Laber, Rasheed, \& Khursheed, 2016; Hadi, 2017). But to the best of our search and knowledge, very rare studies can be found on this topic, particularly in developing country like Pakistan. So the current study aims to investigate the impact of financial literacy and behavioral biases on portfolio diversification, either investors rely on their personal biases or make rational decisions based on their financial education and to investigate the relationship between behavioral biases and portfolio diversification of investors trading in Pakistan Stock Market.

This study also uses socio-demographic factors as control variables. The study helps to understand the importance of financial literacy and derives that investors rely on behavioral biases or they are rational in choosing assets in portfolio. Pakistan Stock Market is often viewed as inefficient market and information about market condition are rarely available to investors. The present study contributes to existing literatures in several ways. It investigates the influence of financial literacy on portfolio diversification and also the 
influence of different behavioral biases in Pakistan Stock Market. The study claims to be the first contribution particularly in the developing country. It also strengthens the efforts of potential researchers in the areas and further encourages them to extend the study. The structure of the paper is as follow; first the paper discussed some past literatures; second, the paper discussed about the model; third, mentioned about methodology and finally analysis of data, results and discussion.

\section{Literature Review}

\section{Financial Literacy and Portfolio Diversification}

Financial literacy is rare in developed and developing countries of the world. Even basic financial literacy is less than desirable, thus financial illiteracy has become the global problem (Lusardi \& Mitchell, 2011; Ates, Sahin, \& Demircan, 2016). Despite, Jariwala (2015) explored that financial literacy has significant impact on investor financial decision making. Financial information and education boost and make confidence in investors for good financial management decision. Chu et al. (2016) scrutinized that individuals with higher financial literacy prefer to invest in mutual fund and intend positive investment return while overconfident financial literate individuals like to hold stocks in portfolio. Gaudecker and Von (2015) illustrated, that the largest loss from under-diversification happened to those investors who neither take help from others nor have their own financial understanding. The study also found that households with financial literacy have fair investment outcomes while individuals who have low financial literacy and who believe in their own decision making, face losses. Jappelli and Padula (2014) found that financial literacy has positive correlation with investors' wealth and portfolio diversification and suggested that financial literacy allows investor better investment opportunities. Dimmock, Kouwenberg, Mitchell, and Peijnenburg (2016) pointed out that financial literacy improves the financial decisions of investor and reduces the ambiguity aversion. Bachmann and Hens (2015) elucidated that investors who rely on professionals' advice and consult with others, have higher investment because they consistently learn from financial advisors. Zhang (2014) derived that individuals, who seek for advice, hold more risky and diversified assets as compared to non-advise seeker. Mouna and Anis (2015); Letkiewicz and Fox (2014); scrutinized that financial literacy has positive impact on portfolio diversification, lack of financial literacy leads less portfolio diversification. Based on available evidences, the study proposed hypothesis;

$H_{1}$ : There is positive relationship between financial literacy and portfolio diversification

\section{Familiarity Bias and Portfolio Diversification}

According to Foad (2011), familiarity bias arises in to two forms; domestic (local biases) and international (home biases). Local biases occur when investor shows his preference to assets within his country to which he is more familiar, he prefers domestic assets portfolio diversification even he could gain from unknown or international portfolio diversification. 
While home biases come when an investor invests large amount of money in domestic equities despite of large gain he may receive from international portfolio diversification. Familiarity bias arises from extra difficulties concerned with investing in foreign portfolio such as additional transaction cost and legal restriction etc. Both cases of biases happened when an investor holds biased portfolio against unbiased portfolio. Kubilay and Bayrakdaroglu (2016) investigated the relationship between investor biases (personality traits and psychological biases) and financial decision making and found that investor biases have significant influence on financial decision making. Shinagawa (2014) resulted that a country with high home biases will be less diversified from foreign financial market while a country with less home biases has large amount of assets portfolio diversification. Mouna and Anis (2015) scrutinized that investors return by portfolio stock is influenced by familiarity biases. Therefore, the study proposed hypothesis:

$H_{2}$ : There is negative relationship between familiarity bias and portfolio diversification

\section{Availability Bias and Portfolio Diversification}

Availability bias refers to the bias where investor relies on already available information. People often rely on ease having past information or experience (Tversky \& Kahneman, 1974). People mostly prefer to those stocks of which they have already available information, knowledge or experience (Chiodo, Guidolin, Owyang, \& Shimoji, 2003). In Pakistan, investors significantly rely on those stocks about which they can easily access and have awareness (Khan, Naz, Qureshi, \& Ghafoor, 2017). Typically, investors give more weight to those stocks which are easily available unlike those which have difficulty to be accessed instead of diversification (Pompian, 2011). Thus, people normally prefer to the local rather than international stocks because about local stocks, they can get more information from friends and relatives to make decisions about their investment. Moreover, In Pakistan, availability bias plays significant role in investment decisions (Abdin \& Sultana, 2017). Empirical results indicated that there is a significant relationship between availability bias and investment decision (Moradi, Mostafaei, \& Meshki, 2013). Yin and Gan (2015) scrutinized that investors increase their investment in those stocks having full information and easy access (i.e. local stocks) and decrease their investment in those stocks having difficulty to be accessed (international stocks). Thus, availability bias has positive influence on local stocks while negative influence on international stocks. Therefore, we propose hypothesis:

\section{$H_{3}$ : There is negative relationship between availability bias and portfolio diversification}

\section{Overconfidence Bias and Portfolio Diversification}

Overconfidence has been defined as the investors' inclination to overemphasize the correctness of their knowledge about the value of security or stocks (Odean, 1999). Overconfidence varies from male to female when they invest in stock market. Men are more overconfident i.e. men trade is $45 \%$ more than women as well as female are more risk averse than men (Barber \& Odean, 2001; Agnew \& Harrison, 2017). Young individuals with low income and 
low education have more overconfidence in portfolio stock investment. Overconfidence has negative influence on portfolio wealth (Barber \& Odean, 2001). In portfolio investment decision making process, individuals always make errors because they rely on available information i.e. behavioral biases and they also repeat some of the biases like overconfidence, representative and anchoring etc. due to which investors do not act rationally (Sukanya \& Thimmarayappa, 2015). Overconfident investors invest too much in the stock familiar to them, and thus the people invest in their local companies even it is bad for diversification point of view (Singh, 2012). Mouna and Anis (2015) scrutinized that low level of financial literacy, low level of financial education and financial concept limit the successful opportunities for stock market participation. Fuertes et al. (2012) resulted that overconfident investors show less and poorer portfolio diversification. Yilmaz and Mazzeo (2014) said when firms appoint overconfident CEO; the firm's stock prices are significantly and negatively affected. Merkle (2017) depicted that overconfident investors engage in excessive trading and under-diversification portfolio and they also involve in risky activities. Mouna and Anis (2015) pointed that overconfident investors rely on their own information and prefer own portfolio over diversification. They also empirically resulted that overconfidence is negatively related to portfolio diversification. Based on the existence evidences and results, the present study proposed hypothesis:

\section{$H_{4}$ : There is negative relationship between over confidence bias and portfolio diversifi- cation}

\section{Portfolio Size and Portfolio Diversification}

"How much assets make good portfolio diversification?" To answer the question, different authors have suggested the number of assets that make good portfolio and minimize risk. Fuertes et al. (2012) described that Turkish investors on average, hold about 2 shares in their equity portfolio diversification which is in contrast of past literature (10-30) while it is close to the countries like Finland and Germany. Mouna and Anis (2015) suggested that investors minimize their transaction cost through investment in different portfolio diversification. They also empirically resulted that portfolio size has positive influence on portfolio diversification. Generally, when an investor aims to invest large amount of money, he/she does not invest in a single asset but diversify his/her assets to minimize risk. The study proposed hypothesis;

$H_{5}$ : There is a positive relationship between portfolio size and portfolio diversification

\section{Methodology}

\section{Sample Size and Data Collection}

The present study used structured questionnaire to collect data from investors trading in Pakistan Stock Exchange. 350 questionnaires were distributed among investors of which 205 questionnaires were received back. Some of the questionnaires were filled incorrectly 
and were not providing accurate information according to the requirements of this study, so these questionnaires were excluded from the study and only 181 questionnaires were included in final analysis. The response rate was $51.71 \%$.

\section{Research Model}

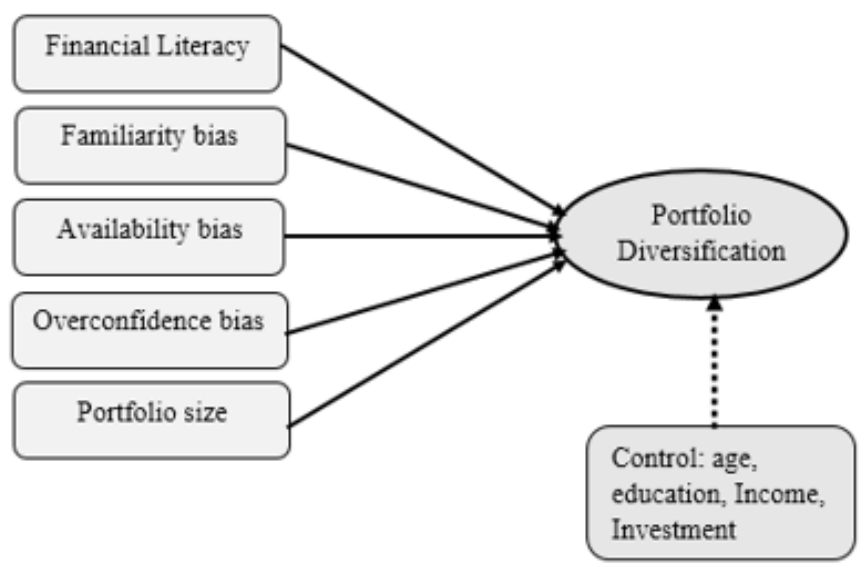

\section{Measurement of Variables}

\section{Financial Literacy}

Financial literacy can be measured in different ways. Lusardi and Mitchell (2011) elaborated that financial literacy has been divided into two main parts; basic financial literacy and advance financial literacy. Basic financial literacy is concerned with interest rate, inflation and return and advance financial literacy contains the items about stock market, financial institutions etc. Financial literacy is measured with different dimensions. The current study used three questions to measure financial literacy basically established by Lusardi and Mitchell (2011) and the mostly recommended dimensions. The questions were related to interest rate and inflation etc. Respondents gave correct answers of all the three or two questions considered financial literate, while in contrast it is considered non-financial literate where two or all the three questions found incorrect.

\section{Familiarity and Availability Biases}

These biases are adopted from Mouna and Anis (2015). Each bias is measured with four items. To know about familiarity bias, the respondents were asked questions "I try to avoid investing in companies with a history of poor earnings" and "I trust the research and past performance of the stocks composed my portfolio" etc. similarly, for availability 
bias the questions asked "Stocks that come quickly to mind are those that displayed the highest class" and "Stock with return of 20 percent, much higher than the market so this stock is the better one to buy" etc.

\section{Overconfidence}

Overconfidence: Either investors are overconfident or not, the four questions were asked "I am an experienced investor" and "I feel more confident in my own investment opinions over opinions of my colleagues or friends" etc. adopted from Mouna and Anis (2015). Overconfidence, familiarity and availability biases are measured through 4 items respectively.

\section{Portfolio Diversification}

The current study relied on the measurement of portfolio diversification as "how much assets or the number of stocks that (diversified) an investor have in his portfolio". After that the median of "the number of assets of the sample" was calculated and finally dummy variable used to compare median of each investor. So, portfolio of the investor is considered diversified if he has more assets than median $=1$. His portfolio is not diversified, if he has less assets in his portfolio than median of sample $=0$. This approach was used by many researchers who measured portfolio diversification particularly in the study of behavioral finance (Toma, 2015; Abreu, 2010; Mouna \& Anis, 2015; Essayyad \& Desai, 2008).

\section{Control Variables}

The current study used few control variables particularly concerned with investors' demographic factors such as age, gender, experience, income and total investment as recommended by prior studies that demographic factors are better to be controlled (Norden, 2010; Milfont \& Gouveia, 2006; Rabinovich, Morton, \& Postmes, 2010). The main purpose of this study is to check the impact of financial literacy and behavioral biases influence on portfolio diversification while controlling investor's socio-demographic factor. Control variables reduce endogenous problems and also minimize spurious results. However, we used dummy variables for gender and performed ANOVA in SPSS to check the influence of gender on portfolio diversification. The ANOVA results shown that gender has no significant influence on portfolio diversification, thus we dropped gender as a control variable from further analysis. The rest of the control variables are tested in main regression test and the results indicated that age, annual income and investment have significant influence on investor portfolio diversification in the emerging market.

\section{Demographics Detail of the Investors}

As per table 1, demographic details of the respondents show that 152 male and 29 female participated in the survey. Concerned with age, $17.1 \%$ of the study respondents have age between 18 and 30, 41 respondents were of age between 31-40, 63 respondent's ages were between 41 to 50 while only one respondent found who's age is above 60 . Regarding education of respondents, 50 participants have education bachelor and below while 131 have 
master and above education. It depicts that the study participants are highly educated. Annual income of the respondents were shown in US Dollar where 38 respondents have annual income ranged from $\$ 5,000$ to $\$ 7,000,42$ respondents have annual income started from $\$ 7,100$ to $\$ 9,000$ while 51 respondents have annual income $\$ 9100$ to $\$ 11,000$ and 50 participants have annual income more than $\$ 11,100$ and above. Concern about investment of the respondents, 36 respondents have invested $\$ 500$ or below, 58 participate have invested $\$ 510$ to \& 1,000 while 36 respondents have investment $\$ 1,100$ to $\$ 1500$. However, 51 respondents have investment $\$ 1,510$ and above.

Table 1

Demographic Profile of the Respondents

\begin{tabular}{lcccc}
\hline & Out of Total & $\begin{array}{l}\text { Percentage out } \\
\text { of total }\end{array}$ & Mean & S.D \\
\hline Gender & 152 & 84 & & \\
1. Male & 29 & 16 & & \\
2. Female & 181 & 100 & 1.16 & 0.368 \\
\hline Total & & & & \\
\hline Age-Years & 31 & 17.1 & & \\
1. $18-30$ & 41 & 22.7 & & \\
2. $31-40$ & 63 & 34.8 & & \\
3. $41-50$ & 45 & 24.9 & & \\
4. $51-60$ & 1 & 0.6 & & \\
5.61 and above & 181 & 100 & 2.69 & \\
\hline Total & & & & \\
\hline Education & 50 & 27.6 & & \\
1. Bachelor and below & 131 & 72.4 & & \\
2. Master and above & 181 & 100 & 1.72 & \\
\hline Total & & &
\end{tabular}

\begin{tabular}{lcccc}
\hline Annual Income\$*. & & & & \\
1. $5,000-7,000$ & 38 & 21 & & \\
2. $7,010-9,000$ & 42 & 32.2 & & \\
3. $9,010-11,000$ & 51 & 28.2 & & \\
4. 111,00 and above & 50 & 27.6 & & 1.102 \\
\hline Total & 181 & 100 & 2.62 & \\
\hline
\end{tabular}

\begin{tabular}{|c|c|c|c|c|}
\hline \multicolumn{5}{|c|}{ Total Investment in Assets\$. } \\
\hline 1. 500 or below & 36 & 19.9 & & \\
\hline 2. $5,100-1,000$ & 58 & 32 & & \\
\hline 3. $11,00-1,500$ & 36 & 19.9 & & \\
\hline 4. 1,510 and above & 51 & 28.2 & & \\
\hline Total & 181 & 100 & 2.56 & 1.102 \\
\hline
\end{tabular}

\section{Results}

\section{Reliability}

To measure the internal consistency of observed factors, Cronbach's alpha was used in the current study. Measure is considered trustable if it provides the same results again and again. The reliability value above (0.60) is suggested as acceptable in general. In the 
current study familiarity bias has reliability value (0.70), availability bias has (0.69) while overconfidence bias has reliability value (0.84). Therefore, the current study has good reliability values for each variable.

\section{Correlation}

Table 2 shows the correlation among study variables. It provides initial support for the proposed hypothesis in the study. Age of the respondents shows negative relationship with portfolio diversification while education, annual income and investment in assets have positive correlation with investor's portfolio diversification. As per study hypothesis, where financial literacy was found to be insignificant and have positive relationship with investor's portfolio (divarication). The analysis shows $(\mathrm{r}=.046, \mathrm{p}>0.05)$ that there is insignificant and weak positive correlation between financial literacy and portfolio diversification. The value $(\mathrm{r}=0.020, \mathrm{p}>0.05)$ shows that familiarity bias has insignificant and weak positive association with portfolio diversification. The value $(\mathrm{r}=0.037, \mathrm{p}>0.05)$ shows that there is insignificant and weak positive relationship between availability bias and portfolio diversification. The value $(\mathrm{r}=-0.307, \mathrm{p}<0.01)$ shows that there is significant and negative relationship between overconfidence bias and portfolio diversification. Portfolio size has positive relationship with investor's portfolio diversification supported in correlation results $(\mathrm{r}=0.066, \mathrm{p}<0.01)$. It clearly depicts that as the investors increase their investment in portfolio, they tend to diversify their investment in different securities and stocks to minimize risk.

Although, formal hypothesis were not proposed between independent variables (biases) but the correlation analysis shows that there is positive relationship between availability and familiarity biases, negative relationship between familiarity and overconfidence biases and negative relationship between overconfidence and availability biases.

\section{Regression Analysis}

The model summary of the regression results shows $(\mathrm{R} 2=0.212, \mathrm{p}<0.01)$ that all the variables used in the study bring $21.2 \%$ variation in portfolio diversification. The overall model is fit on the basis of the significance value at 0.01 level.

Table 3 shows main results of the study. According to the step 3 of table 3 , demographic factors such as age has significant and negative influence on portfolio diversification with value $(\beta=-0.146, \mathrm{p}<0.05)$. Education of the respondents has positive but insignificant impact on portfolio diversification with value $(\beta=0.184, \mathrm{p}>0.05)$ while annual income and investor's investment in portfolio has significant and positive influence on portfolio diversification with value $(\beta=0.168, \mathrm{p}<0.01$, and $\beta=0.135, \mathrm{p}<0.05)$ simultaneously. It depicts that increase in investor's income brings positive change in portfolio as well as when investors increase their investment, they tend to invest in different assets. The overall control variables bring $14 \%$ significant variation in portfolio diversification $(\mathrm{R} 2=0.14$, $\mathrm{p}$ $<0.001)$. 
Table 2

Correlation Coefficients

\begin{tabular}{|c|c|c|c|c|c|c|c|c|c|c|}
\hline Variables & 1 & 2 & 3 & 4 & 5 & 6 & 7 & 8 & 9 & 10 \\
\hline 1. Age & - & & & & & & & & & \\
\hline 2. Education & 0.054 & - & & & & & & & & \\
\hline 3. Annual Income & $.169^{*}$ & 0.025 & - & & & & & & & \\
\hline 4. Investment & 0.094 & 0.036 & $.175^{*}$ & - & & & & & & \\
\hline 5. Financial Literacy & 0.048 & 0.089 & 0.055 & 0.063 & - & & & & & \\
\hline 6. Familiarity bias & 0.064 & 0.107 & 0.131 & -0.006 & -0.011 & -0.7 & & & & \\
\hline 7. Availability bias & 0.029 & 0.014 & 0.054 & 0.105 & -0.071 & $.232^{* *}$ & -0.69 & & & \\
\hline 8. Overconfidence bias & -0.002 & -0.074 & $-.254^{* *}$ & 0.008 & -0.03 & $-.313^{* *}$ & $-.169^{*}$ & -0.84 & & \\
\hline 9. Portfolio Size & 0.074 & 0.065 & $.170^{*}$ & 0.047 & -0.001 & 0.061 & 0.107 & -0.041 & - & \\
\hline 10. P. Diversification & -0.095 & 0.102 & $.269 * *$ & $.186^{*}$ & 0.046 & 0.02 & 0.037 & $-.307^{* *}$ & $.066^{* *}$ & - \\
\hline
\end{tabular}

$H_{1}$ was proposed that there is a positive relationship between financial literacy and portfolio diversification is not supported in the study. The value $(\beta=0.015, \mathrm{p}>0.05)$ shows that financial literacy has positive but insignificant impact on portfolio diversification. It shows that financial literate individuals do not tend to diversify their portfolio.

As per $\mathrm{H}_{2}$ of the study, that there is negative relationship between familiarity bias and portfolio diversification. This hypothesis is not supported in main results of the study. The value in the third step of table $3(\beta=-0.175, \mathrm{p}>0.05)$ describes that familiarity bias has insignificant and negative influence on portfolio diversification. Investors rely on familiarity bias don't diversify their portfolio. They invest in those assets which are well familiar to them.

$H_{3}$ of the study, that there is negative relationship between availability biases and portfolio diversification. The hypothesis is not supported in the current study results with value $(\beta=-0.027, \mathrm{p}>0.05)$ argue that availability bias has insignificant and negative influence on portfolio diversification. Investors invest in those assets which can be easily accessed and come into their mind quickly i.e. local assets and stocks are considered good investment opportunity by them. They do not rely on rationale process to diversify and invest in different assets to reduce loss.

$\mathrm{H}_{4}$ of the study proposed that there is negative relationship between overconfidence bias and portfolio diversification. This hypothesis of the study is supported based on the present study results. Referring to the beta value $(\beta=-0.375, \mathrm{p}<0.001)$ describes that overconfidence has negative and significant influence on investor's portfolio diversification. Overconfident investors trust in their confidentiality rather than to focus on loss reduction through investment in different assets and stocks which make diversified portfolio. It can be argued that overconfident investors believe in their personal experience and trust on their previous investment and then signal and estimate future concern.

$H_{5}$ was proposed that there is positive relationship between portfolio size and portfolio diversification. This hypothesis is also supported in the current study results with concluded value $(\beta=0.072, \mathrm{p}<0.001)$ elaborates that portfolio size has significant and positive influence on portfolio diversification. It describes that investors reduce their loss by investing in different assets and stocks. Mouna and Jarboui (2015) suggested that investors minimize their transaction cost through investment in large number of assets and 
stocks.

Table 3

Regression Results Portfolio Diversification

Portfolio Diversification

\begin{tabular}{|c|c|c|c|c|}
\hline & & $\beta$ & $R^{2}$ & $\beta R^{2}$ \\
\hline \multicolumn{5}{|l|}{ Step 1} \\
\hline & Age & $-.160^{*}$ & & \\
\hline & Education & 0.215 & & \\
\hline & Annual income & $.234^{* * *}$ & & \\
\hline & Investment & $.126^{* *}$ & $.14^{* * *}$ & $.14^{* * *}$ \\
\hline \multicolumn{5}{|l|}{ Step 2} \\
\hline & Age & $-.146^{* * *}$ & & \\
\hline & Education & 0.184 & & \\
\hline & Annual Income & $.168^{* *}$ & & \\
\hline & Investment & $.135^{*}$ & & \\
\hline & Financial Literacy & 0.015 & & \\
\hline & Familiarity bias & -0.175 & & \\
\hline & Availability bias & -0.027 & & \\
\hline & Overconfidence & $-.375^{* * *}$ & & \\
\hline & Portfolio Size & $.072^{* * *}$ & $.212^{* *}$ & $.072^{* *}$ \\
\hline
\end{tabular}

\section{Discussion}

Previous studies contributed to traditional prospective of investors and their portfolio diversification. However, the present study contributes to behavioral side of investor's financial literacy and portfolio diversification.

Based on the current study results, the $H_{1}$ is not supported financial literacy has positive association with portfolio diversification. Financial literate investors involved to invest in different kinds of assets because they have knowledge about different markets and stocks return. The same results have already found in some previous studies. Gaudecker and Von (2015) resulted that the biggest loss from under-diversification happened to those investors, who neither take help from others nor have their own financial understanding. The study also resulted that households with financial literacy have fair investment outcomes. Our findings are in the line with study of Hibbert, Lawrence, and Prakash (2012) revealed that highly financial literate investors tend to invest in foreign assets and less likely to invest in local equities. They further suggested that financially literate investors have undiversified equity portfolio. These results show that investors' in Pakistan Stock Market do not rely on their financial literacy while making an investment in stock market. Referring to the study of VISA international survey of financial literacy across different countries conducted by Nicolini, Cude, and Chatterjee (2013) indicated that Pakistan has the lowest financial literacy score among all the surveyed countries. In addition, the new survey "financial literacy around the world" shows that $26 \%$ adults in Pakistan are financial literate (Klapper, Lusardi, \& Van O, 2015). Moreover, "Finscope survey" (2009) indicated that in Pakistan $42 \%$ of people have saving accounts, $36 \%$ people are interested in saving account, $48 \%$ people use insurance and $22 \%$ people loan (Xu \& Zia, 2012). The findings of the present study claim that Pakistani investors do not rely on their financial literacy while investing 
in portfolio.

$\mathrm{H}_{2}$ of the study is also not supported. The results show that familiarity biases have insignificant and negative impact on portfolio diversification. Familiar investors do not totally prefer to those assets about which they are familiar. They also rely on portfolio and unknown stocks and assets which make portfolio safer and less risky. The results are same with existing literature such as Johnson and Horan (2013) suggested that it is difficult to explore that the chances of success on investment increase with knowledge and information about the firm or industry. Many of investors limit their investment particularly in those firms which are familiar with market trends. (Tekce, Yilmaz, \& Bildik, 2016) concluded that investors with low familiarity bias earn lower return from their investment while investors with higher familiarity bias have positive impact on return. The present study results are in the line with Tekce et al. (2016) resulted that familiarity bias has "nonmonotonic" influence on investment. So, the study also argues that investors who are trading in Pakistan Stock Market are not totally investing in those stocks about which they are familiar. They also consider portfolio diversification i.e. risk reduction while making investment in assets and stocks.

Concerning with $\mathrm{H}_{3}$ that is not supported in the present study. It was proposed that availability bias has negative relationship with portfolio diversification. This result elaborate that investors do not only rely on information easily available to them, they also consider those stocks which minimize their risk. Our results are in the line with prior study of Kong and Fan (2017) who empirically argued that availability bias has no significant role in stock market participation. In addition, there may be several other reasons, for instance, Ke and Wang (2009) suggested that investors prefer local stock and limited securities because they have little information about portfolio diversification and international stocks. In present study, the results of the familiarity and availability biases lead to establishment of new theory related to biases such as "investors in developing countries do not totally rely on information available to them and familiar stocks, they also keep one eye on risk reduction through stock diversification".

The $H_{4}$ of the study is supported that overconfidence bias has negative association with portfolio diversification. Here, it can be claimed that overconfident investors rely on their personal confidence, experience and judgment rather than to invest in different assets and stocks. They believe in themselves instead of large investment in different kinds of stocks and assets. This result is in the line with some previous studies such as Mouna and Anis (2015) found that overconfident investors do not believe in portfolio diversification but they make investment on their personal experience and judgment. Merkle (2017) stated that overconfident investors have active involvement in risky activities and they don't concern with portfolio diversification. The last hypothesis 5 of the study is also supported in the current study results. Portfolio size of investors has positive relationship with portfolio diversification. In general, as investment in portfolio is increasing, investors are trying to invest in different assets and stocks. Mouna and Anis (2015) suggested that investors are trying to reduce their trading expenses and transactions cost by investing large amount in different kinds of stocks and assets.

Hence, the present study argues that investors trading in Pakistan Stock Market are not tended toward familiarity and availability biases. Information availed by them and 
familiar stocks do not influence their decisions about investment in stocks. Normally they rely on their confidence and make their investment. Even financial literate investors also do not thinking about their portfolio diversification, our results strongly support the findings of Chu et al. (2016) who scrutinized that financial literate investor don't tend to invest in portfolio diversification, however overconfidence significantly diversify their portfolio. In addition, our study supports the findings of Zia, Ilyas Sindhu, and Haider Hashmi (2017) that overconfidence bias has significant influence on investor trading in Pakistan stock market. However, as the size of their portfolio increases, they tend to diversify their portfolio. As noted that Pakistan Stock Market is deemed to be inefficient market and information about market are not available freely to investors.

\section{Contribution of the Study}

Although prior studies have significantly contributed to the available literature of behavioral biases and investment decisions (Aren \& Aydemir, 2015; Hoffmann et al., 2013; Johnson \& Horan, 2013; Prosad et al., 2015). However, this study makes empirical contribution to the existing literature on investor's biases, financial literacy and portfolio diversification. The findings of the study reveal that investor's biases have significant influence on portfolio diversification. The findings of the study partially support "behavioral decision theory" of Slovic, Fischhoff, and Lichtenstein (1977) which demonstrates that investors' behaviors influence their decisions. For instance, this study argues that overconfidence bias has significant influence on portfolio diversion while familiarity and availability biases have not significant influence. Unlike prior studies such Mouna and Anis (2015); Letkiewicz and Fox (2014); Abdin and Sultana (2017) who argued that financial literacy, familiarity and availability biases have significant influence on investor's decision, this study found no significant relationship. Hence this study opened a new zone for potential researchers in the respective field for testing the behavior theory empirically.

\section{Implication for Practice}

Based on results, the study claims that investors diversify their portfolio even they are familiar and have information about particular stocks. Financial literacy plays minor role in investor's portfolio diversification. However, it is necessary that investors must be financial literate which helps them how to manage assets and minimize risk. Different investors have different attitude and behavior in stock trading. Some investors rely on their personal judgment, estimation and experience while others believe in familiar stocks and assets. However, portfolio size and financial literacy help investors in trading and investment. It tells them how to make a good portfolio which makes their investment diversified and safe. An investor must have not to fully focus on their biases but has to be considered traditional aspects as well as financial education which may reduce their potential loss.

The findings of the study suggest that government may initiate financial literacy trainings and courses to facilitate investors. As discussed earlier that around the world, Pakistan has the lowest financial literacy score. However, it is argued that high financial literate 
individual invest money in such a way that it gives high return (Gaudecker \& Von, 2015). Although, Pakistan has already established programs to support financial literacy but still the specific schemes are needed to work actively on the improvement of financial literacy.

\section{Limitation and Future Research}

The study is not free of limitations. It has several limitations such as small sample size and only few specific behavioral biases. Statistical tests run in the study also may have limitation because good results can be obtained through different statistics tests i.e. using Structural Equation Modeling (SEM).

To overcome these limitations, large sample size and other behavioral biases such as anchoring bias, representative bias and heuristic bias may be added to get comprehensive and beneficial insights.. However, financial literacy can be put as moderator to check the influence of behavioral biases. Moreover, future research can be conducted in other developing countries which can make additional contribution to the study.

\section{Conclusion}

Previous studies discussed about how investors invest in stocks, assets and securities to minimize risk and maximize return. However, majority of those studies focused on traditional approaches and behavioral biases. The current study aims to check the impact of behavioral biases and financial literacy on portfolio diversification in Pakistan Stock Market by using survey of 181 investors. The results show that behavioral biases such as familiarity and availability biases have insignificant and negative impact on investor's portfolio diversification while overconfidence has significant and negative influence on portfolio diversification. Investors are not significantly influenced by their familiarity and availability biases but they also think about portfolio diversification to minimize risk. The study argues that investors trust on their confidence instead of diversification in various stocks that can minimize risk. Financial literacy has insignificant and positive influence on portfolio diversification. Similarly, portfolio size also has significant and positive association with portfolio diversification of investors. 


\section{References}

Abdin, Z., S, \& Sultana, N. (2017). The impact of heuristics on investment decision and performance: Exploring multiple mediation mechanisms. Research in International Business and Finance, 42, 674-688. Retrieved from https://doi.org/10.1016\% 2Fj.ribaf.2017.07.010 doi: 10.1016/j.ribaf.2017.07.010

Abreu, M. (2010). Financial literacy and portfolio diversification. Quantitative Finance, 10(5), 515-528. Retrieved from https://doi.org/10.1080\%2F14697680902878105 doi: $10.1080 / 14697680902878105$

Agnew, S., \& Harrison, N. (2017). The role of gender, cognitive attributes and personality on willingness to take risks. Business and Economic Research, 7(1), 1-16. Retrieved from https://doi.org/10.5296\%2Fber.v7i1.10371 doi: 10.5296/ber.v7i1.10371

Aren, S., \& Aydemir, D., S. (2015). The factors influencing given investment choices of individuals. Procedia Social and Behavioral Sciences, 210, 126-135. Retrieved from https://doi.org/10.1016\%2Fj.sbspro.2015.11.351 doi: 10.1016/j.sbspro.2015 .11 .351

Ates, S., Sahin, A., M, \& Demircan, L. S., M. (2016). Impact of financial literacy on the behavioral biases of individual stock investors: Evidence from Borsa Istanbul. Business and Economics Research Journal, 7(3), 1-19. Retrieved from https:// doi.org/10.20409\%2Fberj. 2016321805 doi: 10.20409/berj.2016321805

Awais, M., Laber, F., M, Rasheed, N., \& Khursheed, A. (2016). Impact of financial literacy and investment experience on risk tolerance and investment decisions: Empirical evidence from Pakistan. International Journal of Economics and Financial Issues, $6(1), 73-79$.

Bachmann, K., \& Hens, T. (2015). Investment competence and advice seeking. Journal of Behavioral and Experimental Finance, 6, 27-41. Retrieved from https://doi.org/ 10.1016\%2Fj.jbef.2015.03.001 doi: 10.1016/j.jbef.2015.03.001

Barber, M., B, \& Odean, T. (2001). Boys will be boys: Gender, overconfidence, and common stock investment. The Quarterly Journal of Economics, 116(1), 261-292. Retrieved from https://doi.org/10.1162\%2F003355301556400 doi: 10.1162/003355301556400

Bhutta, T., N, \& AliShah, Z., S. (2015). Do behavioural biases impact corporate entrepreneurship, agency cost and firm performance: Evidence from developed and developing economies? Pakistan Journal of Commerce ES Social Sciences, 9(3), 761-798.

Black, F. (1972). Capital market equilibrium with restricted borrowing. The Journal of Business, 45(3), 444-455. Retrieved from https://doi.org/10.1086\%2F295472 doi: $10.1086 / 295472$

Chiodo, A., Guidolin, M., Owyang, T., M, \& Shimoji, M. (2003). Subjective probabilities: psychological evidence and economic applications. Federal Reserve Bank of St. Louis Working Paper Series, 3(9), 1-51.

Chu, Z., Wang, Z., Xiao, J., J, \& Zhang, W. (2016). Financial literacy, portfolio choice and financial well-being. Social Indicators Research, 132(2), 799-820. Retrieved from https://doi.org/10.1007\%2Fs11205-016-1309-2 doi: 10.1007/s11205-016-1309 
$-2$

Daniel, K., Hirshleifer, D., \& Teoh, H., S. (2002). Investor psychology in capital markets: Evidence and policy implications. Journal of Monetary Economics, 49(1), 139-209. Retrieved from https://doi.org/10.1016\%2Fs0304-3932\%2801\%2900091-5 doi: 10.1016/s0304-3932(01)00091-5

Dimmock, G., S, Kouwenberg, R., Mitchell, S., O, \& Peijnenburg, K. (2016). Ambiguity aversion and household portfolio choice puzzles: Empirical evidence. Journal of Financial Economics, 119(3), 559-577. Retrieved from https://doi.org/10.1016\% 2Fj.jfineco.2016.01.003 doi: 10.1016/j.jfineco.2016.01.003

Essayyad, M., \& Desai, K. (2008). Behavioural portfolio formation using mental accounting in emerging markets: The case of Saudi Arabia. International Journal of Monetary Economics and Finance, 1(3), 263-283. Retrieved from https://doi.org/10.1504\% 2Fijmef.2008.020635 doi: 10.1504/ijmef.2008.020635

Fama, F., E, \& French, R., K. (1992). The cross section of expected stock returns. The Journal of Finance, 47(2), 427-465. Retrieved from https://doi.org/10.2307\% 2F2329112 doi: 10.2307/2329112

Foad, H. (2011). Familiarity bias. In Behavioral finance (pp. 277-294). J, Wiley and S, Inc. Retrieved from https://doi.org/10.1002\%2F9781118258415.ch15 doi: 10.1002/9781118258415.ch15

Fuertes, M., A, Muradoglu, G., \& Ozturkkal, B. (2012). A behavioral analysis of investor diversification. The European Journal of Finance, 20(6), 499-523. Retrieved from https://doi.org/10.1080\%2F1351847x.2012.719829 doi: 10.1080/1351847x.2012 .719829

Gaudecker, H., \& Von, M. (2015). How does household portfolio diversification vary with financial literacy and financial advice? The Journal of Finance, 70(2), 489-507. Retrieved from https://doi.org/10.1111\%2Fjofi.12231 doi: 10.1111/jofi.12231

Ghaffar, S., \& Sharif, S. (2016a). The level of financial literacy in Pakistan. Journal of Education 8 Social Sciences, 4(2), 132-143. Retrieved from https://doi.org/ 10.20547\%2F jess 0421604204 doi: $10.20547 /$ jess 0421604204

Ghaffar, S., \& Sharif, S. (2016b). The level of financial literacy in pakistan. Journal of Education \& Social Sciences -, 4(2), 138-150.

Hadi, F. (2017). Effect of emotional intelligence on investment decision making with a moderating role of financial literacy. China USA Business Review, 16(2), 5362. Retrieved from https://doi.org/10.17265\%2F1537-1514\%2F 2017.02 .002 doi: 10.17265/1537-1514/2017.02.002

Hibbert, M., A, Lawrence, R., E, \& Prakash, J., A. (2012). Can diversification be learned? Journal of Behavioral Finance, 13(1), 38-50. Retrieved from https://doi.org/ 10.1080\%2F15427560.2012.654547 doi: 10.1080/15427560.2012.654547

Hoffmann, O., A, Post, T., \& Pennings, M., J. (2013). Individual investor perceptions and behavior during the financial crisis. Journal of Banking 83 Finance, 37(1), 6074. Retrieved from https://doi.org/10.1016\%2Fj.jbankfin.2012.08.007 doi: 10.1016/j.jbankfin.2012.08.007

Jacobs, H., Muller, S., \& Weber, M. (2014). How should individual investors diversify? an empirical evaluation of alternative asset allocation policies. Journal of Financial 
Markets, 19, 62-85. Retrieved from https://doi.org/10.1016\%2Fj.finmar.2013 .07 .004 doi: 10.1016/j.finmar.2013.07.004

Jappelli, T., \& Padula, M. (2014). Investment in financial literacy, social security, and portfolio choice. Journal of Pension Economics and Finance, 14(04), 369-411. Retrieved from https://doi.org/10.1017\%2Fs1474747214000377 doi: $10.1017 /$ s1474747214000377

Jariwala, V., H. (2015). Analysis of financial literacy level of retail individual investors of Gujarat state and its effect on investment decision. Journal of Business 6 Finance Librarianship, 20(1-2), 133-158. Retrieved from https://doi.org/ 10.1080\%2F08963568.2015.977727 doi: 10.1080/08963568.2015.977727

Johnson, R., R, \& Horan, M., S. (2013). Human capital and behavioral biases: Why investors don't diversify enough. The Journal of Wealth Management, 16(1), 9-21. Retrieved from https://doi.org/10.3905\%2Fjwm.2013.16.1.009 doi: 10.3905/ jwm.2013.16.1.009

Kahneman, D., \& Tversky, A. (1972). Subjective probability: A judgment of representativeness. Cognitive Psychology, 3(3), 430-454. Retrieved from https://doi.org/ 10.1016\%2F0010-0285\%2872\%2990016-3 doi: 10.1016/0010-0285(72)90016-3

Ke, D., \& Wang, Q. (2009). Home bias in foreign investment decisions. Journal of International Business Studies, 41(6), 960-979. Retrieved from https://doi.org/ 10.1057\%2Fjibs.2009.48 doi: $10.1057 /$ jibs.2009.48

Khan, H., H, Naz, T., Qureshi, F., \& Ghafoor, A. (2017). Heuristics and stock buying decision: Evidence from Malaysian and Pakistani stock markets. Borsa Istanbul Review, 17(2), 97-110. Retrieved from https://doi.org/10.1016\%2Fj.bir.2016 .12 .002 doi: $10.1016 /$ j.bir.2016.12.002

Klapper, L., Lusardi, A., \& Van O, P. (2015). Financial literacy around the world. Standard 6 Poor's Ratings Services Global Financial Literacy Survey, 1-28.

Kong, W., \& Fan, Y. (2017). The effects of availability and trust on stock market participation: A cross-sectional study based on China. LUP Student Papers, 3, 1-48.

Kubilay, B., \& Bayrakdaroglu, A. (2016). An empirical research on investor biases in financial decision making, financial risk tolerance and financial personality. International Journal of Financial Research, 7(2), 171-182. Retrieved from https://doi.org/ 10.5430\%2Fijfr.v7n2p171 doi: 10.5430/ijfr.v7n2p171

Kumar, S., \& Goyal, N. (2016). Evidence on rationality and behavioural biases in investment decision making. Qualitative Research in Financial Markets, 8(4), 270-287. Retrieved from https://doi.org/10.1108\%2Fqrfm-05-2016-0016 doi: 10.1108/qrfm-05-2016-0016

Lee, C., Shleifer, A., \& Thaler, R. H. (1991). Investor sentiment and the closed-end fund puzzle. The Journal of Finance, 46(1), 75-109. Retrieved from https://doi .org/10 .1111\%2Fj.1540-6261.1991.tb03746.x doi: 10.1111/j.1540-6261.1991.tb03746.x

Letkiewicz, C., J, \& Fox, J., J. (2014). Conscientiousness, financial literacy, and asset accumulation of young adults. Journal of Consumer Affairs, 48(2), 274-300. Retrieved from https://doi.org/10.1111\%2Fjoca.12040 doi: 10.1111/joca.12040

Lintner, J. (1965). The valuation of risk assets and the selection of risky investments in stock portfolios and capital budgets. The Review of Economics and Statistics, 47(1), 
13-37. doi: $10.2307 / 1924119$

Lusardi, A., \& Mitchell, O. (2011). Financial literacy around the world: An overview. Journal of Pension Economics and Finance, 10(4), 497-508. Retrieved from https:// doi.org/10.1017\%2Fs1474747211000448 doi: 10.1017/s1474747211000448

Markowitz, H. (1952). Portfolio selection. The Journal of Finance, 7(1), 77-91. Retrieved from https://doi.org/10.1111\%2Fj.1540-6261.1952.tb01525.x doi: 10.1111/ j.1540-6261.1952.tb01525.x

Merkle, C. (2017). Financial overconfidence over time: Foresight, hindsight, and insight of investors. Journal of Banking \& Finance, 84, 68-87. Retrieved from https://doi .org/10.1016\%2Fj.jbankfin.2017.07.009 doi: 10.1016/j.jbankfin.2017.07.009

Mian, S., T. (2014). Examining the level of financial literacy among Saudi investors and its impact on financial decisions. International Journal of Accounting and Financial Reporting, 1(1), 312-330. Retrieved from https://doi.org/10.5296\%2Fijafr .v4i2.6487 doi: 10.5296/ijafr.v4i2.6487

Milfont, L., T, \& Gouveia, V., V. (2006). Time perspective and values: An exploratory study of their relations to environmental attitudes. Journal of Environmental Psychology, 26(1), 72-82. Retrieved from https://doi.org/10.1016\%2Fj.jenvp. 2006 .03 .001 doi: 10.1016/j.jenvp.2006.03.001

Moradi, M., Mostafaei, Z., \& Meshki, M. (2013). A study on investors' personality characteristics and behavioral biases: Conservatism bias and availability bias in the Tehran stock exchange. Management Science Letters, 3(4), 1191-1196. Retrieved from https://doi.org/10.5267\%2Fj.msl.2013.03.003 doi: 10.5267/j.msl.2013.03.003

Mouna, A., \& Anis, J. (2013). Financial literacy and decision making: An overview from Tunisia. International Journal of Information, Business and Management, 5(4), $62-230$.

Mouna, A., \& Anis, J. (2015). The factors forming investor's failure: Is financial literacy a matter? Viewing test by cognitive mapping technique. Cogent Economics $\&$ Finance, 3(1). Retrieved from https://doi.org/10.1080\%2F23322039.2015.1057923 doi: $10.1080 / 23322039.2015 .1057923$

Mouna, A., \& Jarboui, A. (2015). Financial literacy and portfolio diversification: An observation from the Tunisian stock market. International Journal of Bank Marketing, 33(6), 808-822. Retrieved from https://doi.org/10.1108\%2Fijbm-03-2015-0032 doi: $10.1108 /$ ijbm-03-2015-0032

Nicolini, G., Cude, J., B, \& Chatterjee, S. (2013). Financial literacy: A comparative study across four countries. International Journal of Consumer Studies, 37(6), 689-705. Retrieved from https://doi.org/10.1111\%2Fijcs.12050 doi: 10.1111/ijcs.12050

Norden, L. (2010). Individual home bias, portfolio churning and performance. The European Journal of Finance, 16(4), 329-351. Retrieved from https://doi.org/ 10.1080\%2F13518470903037813 doi: 10.1080/13518470903037813

Odean, T. (1999). Do investors trade too much? The American Economic Review, 89(5), 1279-1298.

Pikulina, E., Renneboog, L., \& Tobler, N., P. (2017). Overconfidence and investment: An experimental approach. Journal of Corporate Finance, 43, 175-192. Retrieved from https://doi.org/10.1016\%2Fj.jcorpfin.2017.01.002 doi: 10.1016/j.jcorpfin 
.2017 .01 .002

Pompian, M. M. (2011). Behavioral finance and wealth management: How to build optimal portfolios that account for investor biases. USA: John Wiley \& Sons.

Prosad, M., J, Kapoor, S., \& Sengupta, J. (2015). Behavioral biases of Indian investors: A survey of Delhi NCR region. Qualitative Research in Financial Markets, 7(3), 230-263. Retrieved from https://doi.org/10.1108\%2Fqrfm-04-2014-0012 doi: 10.1108/qrfm-04-2014-0012

Rabinovich, A., Morton, T., \& Postmes, T. (2010). Time perspective and attitudebehaviour consistency in future-oriented behaviours. British Journal of Social Psychology, 49(1), 69-89. Retrieved from https://doi.org/10.1348\% 2F014466608x401875 doi: 10.1348/014466608x401875

Roll, R. (1977). A critique of the asset pricing theory's tests part I: On past and potential testability of the theory. Journal of Financial Economics, 4 (2), 129-176.

Ross, A., S. (1976). The arbitrage theory of capital asset pricing. Journal of Economic Theory, 13(3), 341-360. Retrieved from https://doi.org/10.1016\%2F0022-0531\% 2876\%2990046-6 doi: 10.1016/0022-0531(76)90046-6

Sharpe, F., W. (1964). Capital asset prices: A theory of market equilibrium under conditions of risk. The Journal of Finance, 19(3), 425-442. Retrieved from https://doi.org/10.1111\%2Fj.1540-6261.1964.tb02865.x doi: 10.1111/j.1540 $-6261.1964 . t b 02865 . x$

Shinagawa, Y. (2014). Determinants of financial market spillovers: The role of portfolio diversification, trade, home bias, and concentration. IMF Working Papers, 14 (187), 1-24. Retrieved from https://doi.org/10.5089\%2F9781498365628.001 doi: 10 $.5089 / 9781498365628.001$

Singh, S. (2012). Investor irrationality and self-defeating behavior: Insights from behavioral finance. Journal of Global Business Management, 8(1), 116-122.

Slovic, P., Fischhoff, B., \& Lichtenstein, S. (1977). Behavioral decision theory. Annual Review of Psychology, 28(1), 1-39. Retrieved from https://doi.org/10.1146\% 2Fannurev.ps.28.020177.000245 doi: 10.1146/annurev.ps.28.020177.000245

Sukanya, R., \& Thimmarayappa, R. (2015). Impact of behavioural biases in portfolio investment decision making process. International Journal of Commerce, Business and Management (IJCBM), 4(4), 1278-1289.

Tekce, B., Yilmaz, N., \& Bildik, R. (2016). What factors affect behavioral biases? evidence from Turkish individual stock investors. Research in International Business and Finance, 37, 515-526. Retrieved from https://doi.org/10.1016\%2Fj.ribaf. 2015 .11 .017 doi: 10.1016/j.ribaf.2015.11.017

Toma, M., F. (2015). Behavioral biases of the investment decisions of Romanian investorson the bucharest stock exchange. Procedia Economics and Finance, 32, 200-207. Retrieved from https://doi.org/10.1016\%2Fs2212-5671\%2815\%2901383-0 doi: $10.1016 / \mathrm{s} 2212-5671(15) 01383-0$

Tversky, A., \& Kahneman, D. (1974). Judgment under uncertainty: Heuristics and biases. Science, 185(4157), 1124-1131. Retrieved from https://doi.org/10.1126\% 2Fscience.185.4157.1124 doi: 10.1126/science.185.4157.1124

Xu, L., \& Zia, B. (2012). Financial literacy around the world: An overview of the evidence 
with practical suggestions for the way forward. The World Bank. Retrieved from https://doi.org/10.1596\%2F1813-9450-6107 doi: 10.1596/1813-9450-6107

Yilmaz, N., \& Mazzeo, A., M. (2014). The effect of CEO overconfidence on turnover abnormal returns. Journal of Behavioral and Experimental Finance, 3, 11-21. Retrieved from https://doi.org/10.1016\%2Fj.jbef.2014.07.001 doi: 10.1016/ j.jbef.2014.07.001

Yin, W., \& Gan. (2015). Financial availability, financial market participation and household portfolio choice. Economic Research Journal, 50(3), 87-99.

Zhang, C., A. (2014). Financial advice and asset allocation of individual investors. Pacific Accounting Review, 26(3), 226-247. Retrieved from https://doi.org/10.1108\% 2Fpar-04-2013-0030 doi: 10.1108/par-04-2013-0030

Zia, L., Ilyas Sindhu, M., \& Haider Hashmi, S. (2017). Testing overconfidence bias in Pakistani stock market. Cogent Economics $\&$ Finance, 5(1), 1-8. Retrieved from https://doi.org/10.1080\%2F23322039.2017.1289656 doi: 10.1080/23322039 .2017 .1289656 